\title{
Regional Inequality of Sport Facilities in Turkey
}

Murat Çiftçi *

* Trakya Üniversitesi

E-mail: drmuratciftci@gmail.com

Copyright (C) 2015 murat çiftçi. This is an open access article distributed under the Eurasian Academy of Sciences License, which permits unrestricted use, distribution, and reproduction in any medium, provided the original work is properly cited.

\begin{abstract}
The aim of this study was to investigate the level of social utility of distribution of intercity sport facilities in Turkey for people. Atkinson indices were used in the study. Statistical data of TUIK was used for the application. The index coefficients revealed an imbalance in the regional distribution of sport facilities for the people, and a substantial loss of social utility for the people. According to the values calculated for people, the levels of social utility of total sport facilities, facility of winter sports, training hall, tennis court, football field, youth center, other sport fields, small stadium, stadium of athletics, gymnasium, stadium were found to be $22.5,7,15.1,22.4,24.3,37.7,38.8,53.1,54.4,59.9$ and $64 \%$ respectively.
\end{abstract}

Keywords: Social politics, social services, Regional planning, Sport sciences, Demography

\section{Türkiye’de Spor Tesislerinde Bölgesel Dağılımın Dengesizliği}

\section{ÖZET}

$\mathrm{Bu}$ çalışmanın amacı, Türkiye'de spor tesislerinin vilayetler arasındaki dağılımlarından sağlanan sosyal fayda düzeylerinin tespit edilmesidir. Çalışmada Atkinson eşitsizlik endeksi yöntem olarak kullanılmıştır. İstatistiksel veriler ise TUİK'ten alınmıştır. Endeks katsayıları, spor tesislerinin vilayet nüfuslarıyla bölgesel dağılımlarında dengesizliği ve yüksek düzeyde toplumun sosyal fayda kaybının olduğunu ortaya koymaktadır. Tüm spor tesislerinden sağlanan sosyal fayda düzeyi \% 22,5 olup, semt sahalarından \%7; antreman spor salonlarından \% 15,1; tenis sahalarından \% 22,4; futbol sahalarından \% 24,3; gençlik merkezlerinden $\%$ 37,7; diğer spor tesislerinden \%38,8; stadlardan \% 53,1; atletizm stadyumlarından \% 54,4; spor salonlarından \% 59,9; stadyumlardan \% 64 oranında sosyal fayda sağlanabildiği tespit edilmiştir.

Anahtar Kelimeler: Sosyal politika, Sosyal hizmetler, Bölge planlama, Spor bilimleri, Demografi

\section{GíRiş}

Spor, toplum hayatında çok boyutlu etki ve katkıları bulunan bir faaliyet olma özelliğindedir.

Sporun işlevlerine bakıldığında, öncelikle toplumun sağlıklı nesiller yetiştirmesine katkıda bulunmasıyla karşılaşılmaktadır (Zengin ve Öztaş, 2008). Bireylerin spora katılımlarıyla topluma katılımlarının da sağlanıyor olması ve spor yoluyla kurallara uyma, iyi - kötü 
ayrımının farkındalığına ulaşma, başkalarına saygı gösterme, başarı veya başarısızlığı kabullenme gibi özellikleri geliştirip bir gruba dahil olma çerçevesinde aidiyet duygusunu geliştirdiğinden, sosyalleşme sürecindeki önemli değerlerden birisi haline gelmektedir (Şahan, 2008). Özellikle 20. yüzyılın son çeyreğinde, kitlesel ilgiyi ulaşılmasıyla birlikte spor, estetik, teknik ve fiziki bir süreç olma özelliğine bürünmüştür (Tanyeri, 2003). Dolayısıyla da kitlesel ilgi, beraberinde beğenilme güdüsünün de ön plana çıkmasına katkı sağlamış, spor faaliyetinin sosyalleşme sürecinde bir unsur haline dönüşümüne ayrıca katkı sağlamıştır. Bu noktada spor, ister meslek olarak gerçekleştirilen bir faaliyet olsun, isterse de serbest zaman faaliyeti konumunda olsun, belirli kurallar kısıtında gerçekleştirilerek sosyalleştirici olma özelliğine sahip olmuştur (Atasoy ve Öztürk Kuter, 2005).

Sporun sosyalleşme sürecindeki etkisi dışında, günümüzde giderek daha da artan bir diğer işlevi de serbest zaman faaliyeti olma özelliğidir. Bilindiği üzere serbest zaman, dışsal zorlamalarla olmayıp bireysel kontrolle ve özgür iradeyle seçilip, çeşitli kazanımların elde edilerek fiziksel ve ruhsal açıdan yeniden hazır hale gelmek için gerekli olan zaman periyodu özelliğinde olup, spor da rekreatif etkinlikler içerisinde yer almaktadır (Ardahan ve Yerlisu Lapa, 2010). Özellikle günümüzdeki iş yaşamı ve diğer etkinliklerin yoğunluğu ile rutin ve stresli bir yapıya bürünmesi de, serbest zaman kullanımının yeniden toparlanmayı sağlamada ayrıcalıklı bir yere gelmesine yol açmıştır (Tel ve Köksalan, 2008).

Sporun geldiği nokta incelendiğinde, 19. Yüzyıl öncesindeki geleneksel sporlarda sayısal ölçülerle sınırlandırılmayan savaş ve dinin şekillendiriciliğinde ve erkek egemen yapıya sahip oluşu, sanayi inkılabı sonrasında değişerek, rasyonelleşerek yarışmacı rekabeti organize edip kendi politikalarını da oluşturan bir yapıya bürünmüştür (Zelyurt, 2013). Çok fonksiyonlu özelliğe bürünerek önem kazanan spor da çok sayıda branşlara ayrılmıştır. Kitle sporları ayrımına gidildiğinde, performans (zirve) sporları, gösteri sporları, rekreasyon sporları, sağlıklı yaşam sporları, özürlüler için spor, resmi ve resmi olmayan sporlar şeklinde ayrılabilmektedir (Filiz, 2002). Sadece ülkemizde, futbol branşı olimpik ve henüz olimpik olmayan 37 spor branşı federasyon örgütlenmesini tamamlayarak etkinliklerini gerçekleştirmektedirler (Sunay ve Saracaloğlu, 2003).

Kısaca aktarıldığı üzere spor, günümüzde gerek mesleki faaliyet olarak gerekse de nesillerin sosyalleşme süreçlerinin başarıyla tamamlanmasında sağlamış olduğu etkin rolü açısından toplumun bütününü yakından ilgilendiren bir faaliyet özelliğine bürünmüştür. Yapısındaki çeşitlenme ve karmaşıklık da eklendiğinde spor faaliyetlerinin bölgesel olarak ve her yaşa ve nüfus bütününe uyumlu şekilde yapılabilmesine olanak sağlayacak tesislerin 
gerçekleştirilmesinin ayrıcalıklı bir önemi mevcuttur. Bu çalışmada da spor tesislerinin 81 vilayetteki dağ̊lımlarının nüfus ve yaş dilimlerine göre dağılımında yaşanan dengesizliğin yol açtığ1 sosyal (toplumsal) fayda kayıplarına odaklanılmıştır.

Çalışmada kullanılacak olan bölgesel eşitsizliklerin tespitine yönelik uygulanan tekli eşitsizlik endeksleri Gini katsayısından türetilmiştir. Gini katsayısı 1 ile 0 arasında değer almakta olup, 1 tam eşitsizliği yani dağılımı test edilen varlığın tek gözlemde (kişi, bölge vd) toplandığını, o ise tüm gözlemlerde eşit miktarda dağıldığını göstermektedir. Gini katsayısı tekli eşitsizlik endeksleri içerisinde de bilinen ve yaygın olarak kullanılan endeks olma özelliğindedir (Ravallion, 2001; Fedorov, 2002; Moran 2003). Bu yaygın kullanımda Sen (1973)' in de vurguladığı üzere Gini katsayısının 1912' den bu yana kullanılmasını aramak yanlış olmayacaktır. Gini katsayısından türetilerek ortalama veya diğer ölçülerden sapmaya dayanan endeksler, entropi (bilgi teorisi) ile normatif sosyal fayda modellerine dayanan endeksler yaygın olarak kullanılmaktadır. Bunlardan bazıları Dahl endeksi, Nagel endeksi, değişim (varyans) katsayısı, logaritmik değişim (varyans) katsayısı, Theil endeksi, Atkinson endeksi olarak siralanabilir (Chakravorty, 1996).

Eşitsizlik endeksleri ekonomi başta olmak üzere çok sayıda alanda yaygın şekilde kullanılmaktadır. Eşitsizlik endekslerinin bölgesel dağılımdaki dengesizliğin ölçümünde de yoğun olarak kullanıldığı da gözlemlenmektedir. Bu çalışma kapsamında kullanımı tercih edilen Atkinson endeksinin bölgesel dengesizliğin ölçümünde kullanımında da özellikle ekonomi disiplini başta olmak üzere göç, sağlık, eğitim bilimleri gibi çok sayıda disipline dair örneklerle karşılaşılmaktadır (Islam ve Habibullah, 1986; Castro, 2003; Dayığlu ve Başlevent, 2006; Wan, Lu ve Chen, 2007; Çiftçi, 2009;2010,2011; Çiftçi ve Seymen, 2011,2012; Vilaverde ve Maza, 2012; Bleys, 2013).

Spor disipliniyle ilgili uluslararası literatürde eşitsizlik endekslerinin yaygın olarak çeşitli araştırma konularında kullanıldığı görülmektedir. Bu kapsamda ekonomiyle bağlantılı olarak gelir ve performans ilişkisine dair yapılan araştırmalar, liglerde maç kazanma başarısıyla ilgili çalışmalar, sezon uzunluklarındaki değişimlerin rekabete etkileri gibi spesifik çalışmalar örnekler arasında gösterilebilir (Wiseman ve Chatterjee, 2003; Mizak, Stair ve Rossi, 2005; Mizak, Neral ve Stair, 2007; Owen, 2010; Annala ve Winfree, 2011; Dorion ve King, 2015). Dolayısıyla spor ve özellikle de spor ekonomisi bilim disiplinleri, eşitsizlik endekslerinin kullanımına yabanı değildir. Araştırmanın özgün yanı ise, spor disiplininde yaygın kullanıma sahip olan eşitsizlik endeksleri içerisinde Atkinson endeksinin bölgesel eşitsizlik ölçümü olarak kullanılmasından ileri gelmektedir. 


\section{YÖNTEM}

Araştırma Grubu: Çalışma kapsamına 2007 yılı itibarıyla Türkiye'deki 81 vilayetteki spor tesisleri ile vilayet genel nüfusları ve yaş dilimlerine göre vilayet nüfusları alınmıştır. Yaş gruplarına göre vilayet nüfuslarında 0-14 yaş grubundakiler, 15-24 yaş grubundakiler, 25-34 yaş grubundakiler, 35-44 yaş grubundakiler, 45-54 yaş grubundakiler, 55-64 yaş grubundakiler ve 65 yaş ve üstündekiler olmak üzere 7 kategoride sınıflandırmaa gerçekleştirilmiştir. Ancak spor tesislerinin bütün türlerinde 81 vilayete yayılmanın gerçekleşememiş olması sebebiyle, Atkinson katsayılarının ve katsayılara dayalı olarak hesaplanan ülke sosyal fayda düzeyleri ve ülke sosyal fayda kayıpları için gözlemleri oluşturan vilayet sayıları 41 ile 81 arasında değişmiştir.

Veri Toplama Aracı ve İşlem Yolu: Çalışma kapsamında gerçekleştirilen analizde kullanılan verilerden spor tesislerinin vilayetlere göre sayıları TUİK (2008)' in Spor İstatistikleri, 2007 isimli çalışmasından, vilayet genel ve yaş dilimlerine göre nüfusları ise TUIK' in web sitesinden temin edilmiştir. Tanımlayıcı istatistik sonuçları ise tablo 1' de sunulmuştur.

Tablo 1. Tanımlayıcı İstatistikler

\begin{tabular}{lrrrr}
\hline & Ülke toplamı & Ortalama & Standart sapma & N (Gözlem say1s1) \\
\hline Toplam & 9284 & 111,20 & 96,63 & 81 \\
Stadyum & 74 & 1,18 & 0,53 & 61 \\
Stad & 282 & 3,61 & 3,44 & 77 \\
Futbol sahası & 1352 & 16,68 & 15,16 & 80 \\
Spor salonu & 423 & 5,23 & 3,98 & 81 \\
Antrenman spor salonu & 180 & 3,31 & 3,00 & 53 \\
Semt sahaları & 6082 & 73,25 & 86,61 & 80 \\
Tenis sahası & 119 & 2,95 & 4,02 & 41 \\
Atletizm stadyumu & 156 & 2,07 & 2,11 & 73 \\
Gençlik merkezi & 132 & 1,63 & 1,13 & 75 \\
Diğer & 484 & 6,09 & 4,56 & \\
\hline
\end{tabular}

Tanımlayıcı istatistiklerde ülke toplamı (ana kütle), ortalama, standart sapma değerleri ile en az 1 spor tesisi bulunan vilayetlerin analiz kapsamına alınması sebebiyle değişkenlik gösteren gözlem sayıları sunulmuştur. Tanımlayıcı istatistiklerde dişkkat çeken ise üç farklı spor tesisinde standart sapma değerlerinin ortalamaların üzerinde gerçekleşmiş olmasıdır. $\mathrm{Bu}$ sonuçların elde edilmesinde ise vilayetlere göre spor tesisi sayılarında yaşanan dengesizliğin etkisi görülmektedir. Buna göre semt sahalarında 1 ile 329 arasında yüksek düzeyde değişkenlik mevcut olduğundan, standart sapma değeri de ortalamanın üzerinde 
gerçekleşmiştir. Keza bu volatilite tenis sahalarında 1 ile 24 arasında gerçekleşmiş olup, atletizm stadyumlarında da 1 ile 14 arasında değişkenlik göstermiştir.

Veri Analizi: Veri analizinde yöntem olarak Atkinson katsayısı yaklaşımı kullanılmıştır. Elde edilen katsayılardan da yüzde cinsinden sosyal fayda düzeyleri ile sosyal fayda kayıplarının hesaplanması gerçekleştirilmiştir. Gösterge kabiliyeti açısından Atkinson için yapılan çeşitli sınama çalışmalarında, Gini katsayısıyla yüksek ilişkiye sahip olduğu (Harvey, 2005), standart fayda içerikli eşitsizlik endeksleri içerisinde gayet tatminkar performansa sahip olduğu (Salas, 1997) ve hatta en iyi göstergenin Atkinson katsayısı olduğu (Garcia ve Molina, 2001) sonuçlarına varıldığı görülmektedir. Eşitsizlik ölçümünde etik uygulamaların ilk modern uygulama yöntemi olarak Atkinson endeksi, 1970 yılında ismini veren bilim adamı Antony B. Atkinson tarafından geliştirilerek literatüre kazandırılmıştır (Pedersen, 2004, s. 34).

Atkinson katsayısının hesaplanmasında orijinal formül

$$
I=1-\left[\sum_{i}\left(\frac{y_{i}}{\mu}\right)^{1-\varepsilon} f\left(y_{i}\right)\right]^{\frac{1}{1-\varepsilon}}
$$

olarak oluşturulmuştur (Atkinson, 1970). Formülde y gelir düzeyini temsil etmekte olup, $\mu$ ortalama gelir düzeyini, $\varepsilon$ ise farklı gelir düzeyleri için gelir transferine duyarlılık seviyesini tanımlamaktadır.

Bölgelerarası dengesizliğin hesaplanmasındaysa Atkinson katsayısı formülü;

$$
A_{(\Omega)}=1-\left[\frac{P_{i}}{P} \times\left(\sum_{i=1}^{n} \frac{S_{i} / P_{i}}{\bar{S} / \bar{P}}\right)^{1-\Omega}\right]^{\frac{1}{1-\Omega}} \text { ĕger } \Omega \neq 1
$$

olarak dönüştürülmüştür. Formülde “ $A_{(\Omega)}$ ” katsayıyı, “ $P_{i}$ ” i vilayetindeki (genel veya yaş dilimindeki) nüfus miktarını, “ $\bar{P}$ ” vilayet başına düşen ortalama (genel veya yaş dilimindeki) nüfus miktarını tanımlamaktadır. " $S_{i}$ ” i vilayetinde spor tesisi sayısını, “ $\bar{S}$ ” ise vilayet başına düşen ortalama spor tesisi miktarını tanımlamaktadır. Duyarlılık parametresini oluşturan " $\Omega$ " ya verilecek değer konusunda araştırmacılar özgür olmakla birlikte çoğunlukla hesaplamanın kolay yapılabilmesi ile yüksek duyarlılık olduğunun savunulmasından ötürü 2 değeri kullanılmaktadırlar (Öztürk, 2005). Bu parametre varlıklıdan çok varlıklı olmayana, 
yoksuldan da çok yoksul olmayana göre yeniden dağılımına karşılaştırmalı duyarlılığı yansıtmakta olduğundan, daha yüksek $\Omega$ değeri verilmesi durumunda dağılımı hesaplananın transferinin daha düşük olan arka kısmındakilerin duyarlılığının "orta-düşük düzeyde elde eden gözlemler” daha yüksek hissedilmesini sağlamaktadır (Spatz, 2006). Bu sebeple de arka kısımda kalan yoksun kalanların yeniden dağıtımı, varlıklılara göre ölçeksel bazda daha düşük olacaktır ve parametre de bunu standartize etmektedir. Buna ek olarak Atkinson katsayısıyla sosyal fayda düzeyine de ulaşıldığından, bölgelerarası eşitsizlikten kaynaklanan sosyal fayda kaybını rahat şekilde tespit etmek de mümkün olmaktadır. Örneğin elde edilen katsayı 0.15 ise bölgelerarası eşit dağılımda aynı sosyal faydanın [100*(1-Atkinson)] \%85'inden aynı düzeyde sağlanacağı anlamını taşımaktadır (Redigor ve dğ. 2003). Dolayısıyla da katsayı, diğer eşitsizlik ölçülerinden farklı olarak bilimsel çalışmalarda sosyal fayda ve sosyal fayda kayıplarını net olarak ortaya koyan gösterge özelliğine sahip olmaktadır.

Sosyal fayda ve sosyal fayda kayıp oranlarının Atkinson katsayısına dayanarak hesaplanabilmesi, aynı zamanda dağılıma konu olan varlıkların ki bu çalışmada spor tesis miktarlarıdır - sayısal olarak nüfusla tam dengeli dağılımın sağlanması durumunda ne kadarlık miktardaki varlıktan sağlanacak sosyal faydaya eşit olduğunu da gösterme imkanı tanımaktadır. Buna ek olarak mevcut varlık miktarının ne kadarının hissedilemediğinin de tespitini mümkün k1lmaktadır.

Buna göre tam denge durumuna göre hissedilen varlık (spor tesisi) miktarının formülü;

$$
S_{(V, J)}=\left(1-A_{(\Omega)}\right) \times S_{(M, J)}
$$

olarak gerçekleştirilecektir. Formülde “ $A_{(\Omega)}$ ” Atkinson katsayısını, “ $S_{V, J}$ ” J türündeki spor tesislerinden tam denge durumuna göre hissedilenlerin toplam miktarını, “ $S_{V, J}$ ” J türündeki spor tesislerinin mevcut miktarını tanımlamaktadır.

Buna göre tam denge durumuna göre mevcudiyeti hissedilmeyen yani yok olarak hissedilen varlık (spor tesisi) miktarının formülü ise;

$$
S_{(Y, J)}=A_{(\Omega)} \times S_{(M, J)}
$$

olarak gerçekleştirilecektir. Formülde “ $A_{(\Omega)}$ ” Atkinson katsayısını, " $S_{Y, J}$ ” J türündeki spor tesislerinden tam denge durumuna göre mevcudiyeti hissedilemeyen toplam miktarını, " $S_{V, J}$ " J türündeki spor tesislerinin mevcut miktarını tanımlamaktadır. 


\section{BULGULAR}

Ülkemizde spor tesislerinin vilayetlerdeki nüfus miktarlarına göre dağılımlarındaki denge durumuna göre hesaplanan Atkinson eşitsizlik katsayıları, spor tesislerinin dağılımlarında tam denge durumundan oldukça uzak kalındığını teyit etmektedir. Tüm spor tesisleri dikkate alınarak yapılan analizde, ülkemizdeki spor tesislerinin il nüfuslarına göre dengeli dağıtılamamasından dolayı nüfusun spor tesislerinden tam denge durumunun $\% 22.5$ 'i düzeyinde sosyal fayda sağlayabildikleri anlamını taşımaktadır. Dolayısıyla da mevcut spor tesislerinden \%22.5 oranında sosyal fayda sağlayabilmektedirler. Bu oran semt sahalarında \%7'ye kadar düşmekte olup, en yüksek sosyal faydanın sağlandığı stadyumlardan dahi \%64 oranında elde edilebildiğini göstermektedir. En yüksek sosyal faydanın sağlandığı spor tesislerinden en düşük sosyal faydanın sağlandığı spor tesislerine doğru elde edilen sosyal fayda düzeyleri şu şekilde gerçekleşmiştir: Stadlarda \%64 oranında gerçekleşen sosyal fayda düzeyi spor salonlarında $\% 59.9$; atletizm stadyumlarında $\% 54.4$; stadlarda $\% 53.1$; diğer spor tesislerinde \%38.8; gençlik merkezlerinde $\% 37.7$; futbol sahalarında $\% 24.3$; bütün spor tesisleri toplamında \%22.5; tenis sahalarında \%22.4; antrenman spor salonlarında \%15.1 düzeyinde gerçekleşmiştir (Şekil 1).

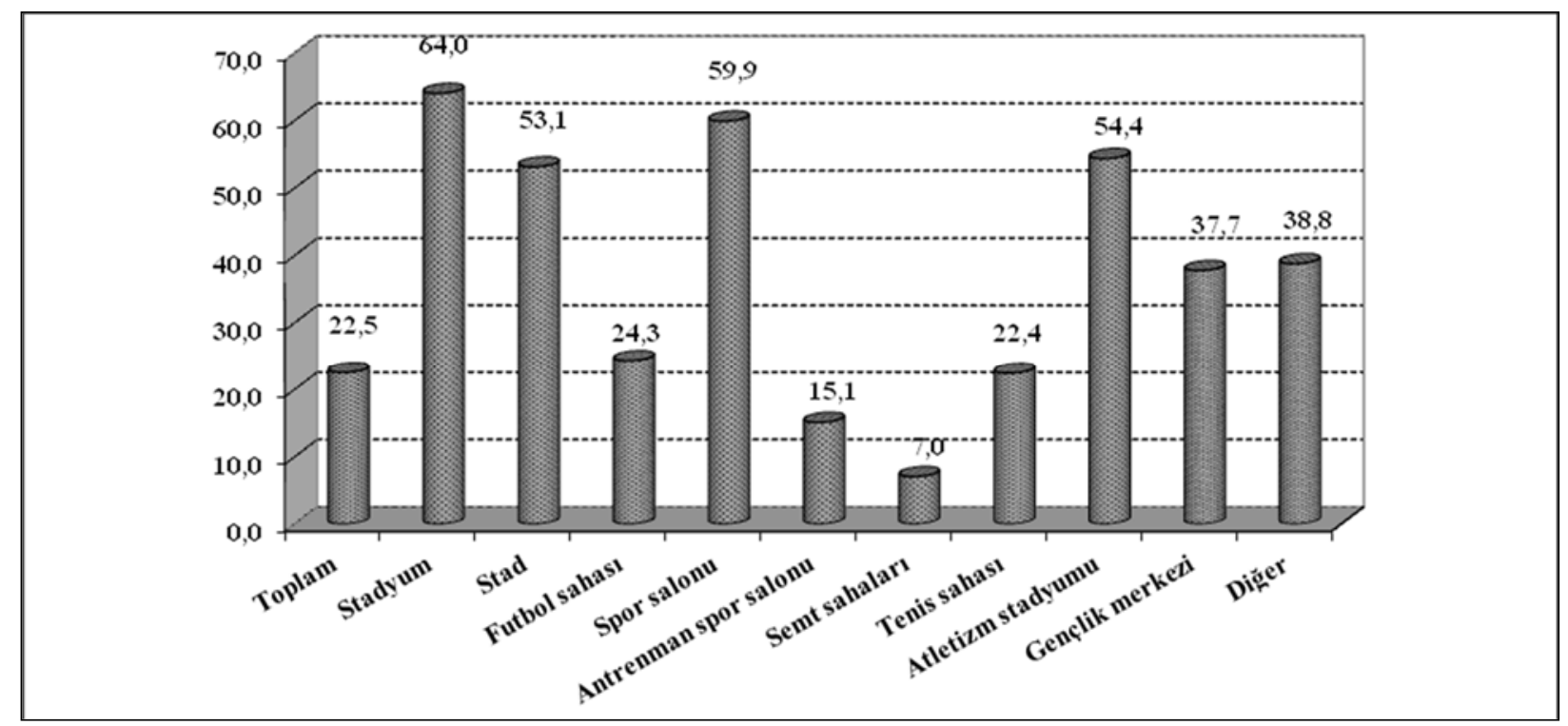

Şekil 1. Türkiye'deki Spor Tesislerinden Nüfusun Sağladığg Sosyal Fayda Düzeyleri

Sosyal fayda kayıpları açısından konu incelendiğinde ise tüm spor tesisleri dikkate alınarak yapılan analizde, ülkemizdeki spor tesislerinin il nüfuslarına göre dengeli dağıtılamamasından dolayı oluşan sosyal fayda kaybı \% $77.5^{\prime}$ e ulaşmış olup, bunun anlamı 
toplum tarafından mevcut spor komplekslerinin \%77.5'inin varlığının hissedilemediği ya da bir aşka ifade ile yokmuş gibi hissedildiğidir. Bu oran semt sahalarında \%93'e kadar çıkmakta olup, en düşük sosyal fayda kaybının yaşandığı stadyumlarda dahi \%64 oranında gerçekleştiği görülmektedir. En düşük sosyal fayda kaybının yaşandığı spor tesislerinden en yüksek sosyal fayda kaybının yaşandığı spor tesislerine doğru elde edilen sosyal fayda kaybı düzeyleri şu şekilde gerçekleşmiştir: Stadlarda \%36 oranında gerçekleşen sosyal fayda kaybı düzeyi spor salonlarında $\% 40.1$; atletizm stadyumlarında \% 45.6; stadlarda \%46.9; diğer spor tesislerinde $\% 61.2$; gençlik merkezlerinde $\% 62.3$; futbol sahalarında $\% 75.7$; bütün spor tesisleri toplamında $\% 77.5$; tenis sahalarında $\% 87.6$; antrenman spor salonlarında $\% 84.9$ düzeyinde gerçekleşmiştir (Şekil 2).

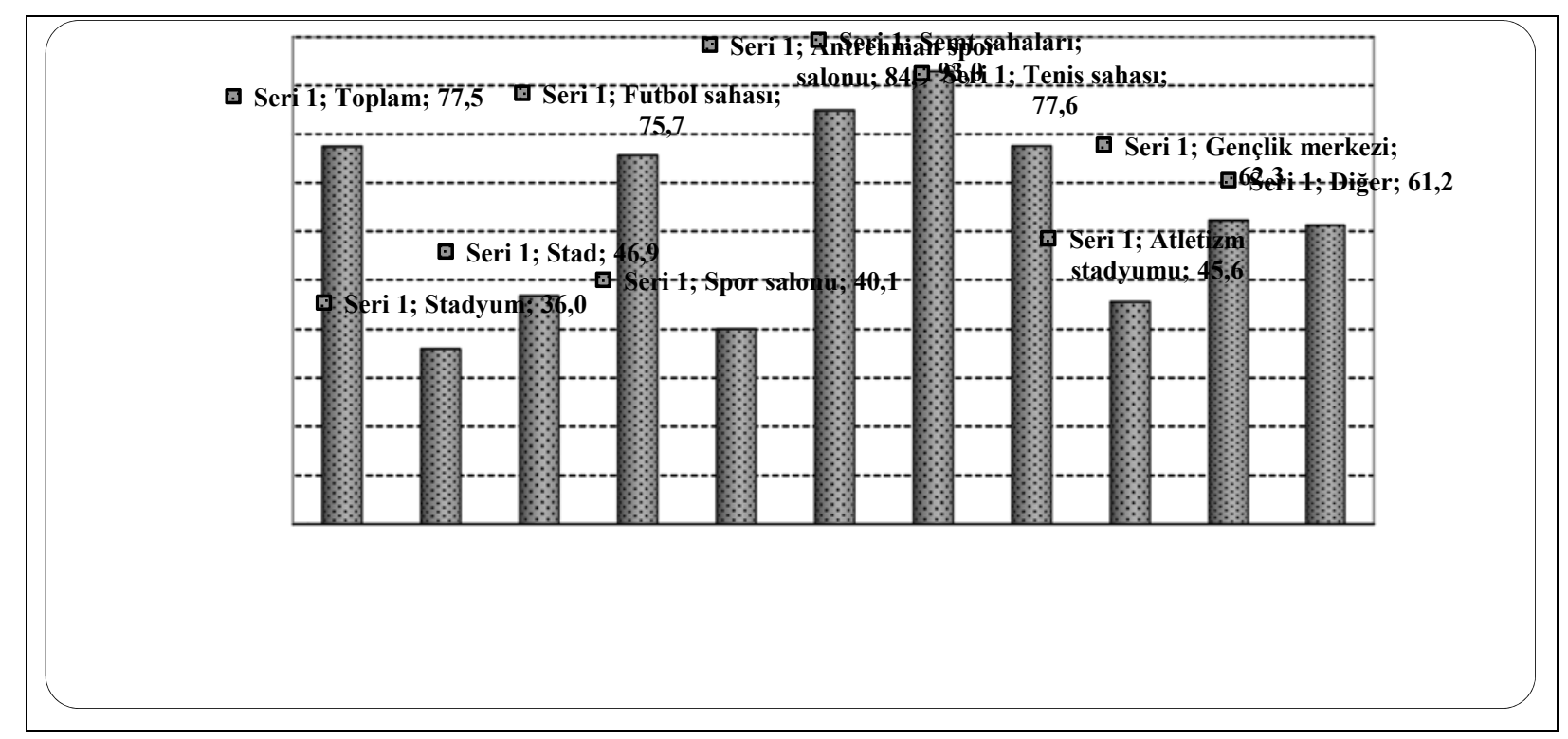

Şekil 2. Türkiye'deki Spor Tesislerinden Nüfusun Sağladığı Sosyal Faydada Kayıplar (\%)

Yaş dilimlerine göre analiz tekrarlandığında daha çok 65 yaş üstü nüfus grubu ön plana çıkmaktadır. Örneğin tüm spor tesislerinin vilayetlere göre dağılımlarından 65 yaş ve üstü yaş grubunun elde ettiği sosyal fayda düzeyi \%29.5'le en yüksek düzeyi oluşturmaktadır. 0-14 yaş grubu için \%23.2; 15-24 yaş grubu için \%23.5; 25-34 yaş grubu için \%18.2'ye; 35-44 yaş grubu için \%19.8; 45-54 yaş grubu için \%22; 55-64 yaş grubu için \%25.3; 65 yaş üstü nüfus için ise \%29.5 olarak gerçekleşmiştir.

Vilayet nüfus bütününe göre en yüksek sosyal faydanın sağlandığı spor tesisi türü olan stadyumlarda yaş dilimlerine göre elde edilen sosyal fayda düzeylerinde de benzer yap1 sürmektedir. 0-14 yaş grubu için \%67.9; 15-24 yaş grubu için \%66.7; 25-34 yaş grubu için 
\%56.5'e; 35-44 yaş grubu için \%57.4; 45-54 yaş grubu için \%58.5; 55-64 yaş grubu için \%62.2; 65 yaş üstü nüfus için ise \%69.2 olarak gerçekleşmiştir.

Vilayet nüfus bütününe göre ikinci en yüksek sosyal faydanın sağlandığı spor tesisi türü olan spor salonlarında yaş dilimlerine göre elde edilen sosyal fayda düzeylerinde de benzer yapı sürmektedir. 0-14 yaş grubu için \%55.7; 15-24 yaş grubu için \%60.4; 25-34 yaş grubu için \%53.2'ye; 35-44 yaş grubu için \%56.6; 45-54 yaş grubu için \%60; 55-64 yaş grubu için $\% 65$; 65 yaş üstü nüfus için ise $\% 71.5$ olarak gerçekleşmiştir.

Vilayet nüfus bütününe göre üçüncü en yüksek sosyal faydanın sağlandığı spor tesisi türü olan atletizm stadyumlarında yaş dilimlerine göre elde edilen sosyal fayda düzeylerinde de benzer yapı sürmektedir. 0-14 yaş grubu için \%53.8; 15-24 yaş grubu için \%56.2; 25-34 yaş grubu için \%46.9'a; 35-44 yaş grubu için \%49.6; 45-54 yaş grubu için \%53.4; 55-64 yaş grubu için \%58.3; 65 yaş üstü nüfus için ise \%64.1 olarak gerçekleşmiştir.

Stadlardan yaş dilimlerine göre elde edilen sosyal fayda düzeyleri; 0-14 yaş grubu için \%46,9; $15-24$ yaş grubu için \%51,7; 25-34 yaş grubu için \%49,5'e; 35-44 yaş grubu için $\% 51,6$; $45-54$ yaş grubu için $\% 54,1$; 55-64 yaş grubu için \%58; 65 yaş üstü nüfus için ise \%63,6 olarak gerçekleşmiştir.

Diğer spor tesislerinden yaş dilimlerine göre elde edilen sosyal fayda düzeyleri; 0-14 yaş grubu için \%32,7; 15-24 yaş grubu için \%38,1; 25-34 yaş grubu için \%34,5'e; 35-44 yaş grubu için \%38; $45-54$ yaş grubu için \%41,7; 55-64 yaş grubu için \%45,5; 65 yaş üstü nüfus için ise $\% 49,4$ olarak gerçekleşmiştir.

Gençlik merkezlerinden yaş dilimlerine göre elde edilen sosyal fayda düzeyleri; 0-14 yaş grubu için \%38,9; 15-24 yaş grubu için \%39,3; 25-34 yaş grubu için \%31,8'e; 35-44 yaş grubu için \%33,7; 45-54 yaş grubu için \%36,3; 55-64 yaş grubu için \%40,3; 65 yaş üstü nüfus için ise \% 45,9 olarak gerçekleşmiştir.

Futbol sahalarından yaş dilimlerine göre elde edilen sosyal fayda düzeyleri; 0-14 yaş grubu için \%26,2; 15-24 yaş grubu için \%25,6; 25-34 yaş grubu için \%19,7'ye; 35-44 yaş grubu için $\% 33,7$; $45-54$ yaş grubu için $\% 36,3$; 55-64 yaş grubu için $\% 40,3 ; 65$ yaş üstü nüfus için ise \%45,9 olarak gerçekleşmiştir.

Tenis sahalarından yaş dilimlerine göre elde edilen sosyal fayda düzeyleri; 0-14 yaş grubu için \%26,2; 15-24 yaş grubu için \%24,5; 25-34 yaş grubu için \%16,9'a; 35-44 yaş grubu için \% 18,7; 45-54 yaş grubu için \%21,1; 55-64 yaş grubu için \%25; 65 yaş üstü nüfus için ise \%30,5 olarak gerçekleşmiştir. 
Antrenman spor sahalarından yaş dilimlerine göre elde edilen sosyal fayda düzeyleri; 0-14 yaş grubu için \%17,4; 15-24 yaş grubu için \%16,4; 25-34 yaş grubu için \%11.4'e; 35-44 yaş grubu için \%12.6; 45-54 yaş grubu için \%14,3; 55-64 yaş grubu için \%17; 65 yaş üstü nüfus için ise \%20,6 olarak gerçekleşmiştir.

Semt sahalarından yaş dilimlerine göre elde edilen sosyal fayda düzeyleri; 0-14 yaş grubu için \%7,8; 15-24 yaş grubu için \%7,5; 25-34 yaş grubu için \%5,5'e; 35-44 yaş grubu için $\% 6$; $45-54$ yaş grubu için $\% 6,8 ; 55-64$ yaş grubu için $\% 8 ; 65$ yaş üstü nüfus için ise \%9,5 olarak gerçekleşmiştir.

Tablo 2. Atkinson Endeksleri, Sosyal Fayda Oranları, Sosyal Fayda Kayıp Oranları

\begin{tabular}{|c|c|c|c|c|c|c|c|c|c|}
\hline & & \multirow[b]{2}{*}{ Toplam Nüfus } & \multicolumn{7}{|c|}{ Yaş Grupları } \\
\hline & & & $0-14$ & $15-24$ & $25-34$ & $35-44$ & $45-54$ & $55-64$ & $65+$ \\
\hline \multirow{4}{*}{$\frac{\Xi}{\frac{\Xi}{a}}$} & Atkinson endeksi & 0.775 & 0.768 & 0.765 & 0.818 & 0.802 & 0.780 & 0.747 & 0.705 \\
\hline & Sosyal Fayda & 22.5 & 23.2 & 23.5 & 18.2 & 19.8 & 22.0 & 25.3 & 29.5 \\
\hline & Sosyal Fayda Kaybı & 77.5 & 76.8 & 76.5 & 81.8 & 80.2 & 78.0 & 74.7 & 70.5 \\
\hline & $\mathbf{N}$ & 81 & 81 & 81 & 81 & 81 & 81 & 81 & 81 \\
\hline \multirow{4}{*}{ 主 } & Atkinson endeksi & 0.360 & 0.321 & 0.333 & 0.435 & 0.426 & 0.415 & 0.378 & 0.308 \\
\hline & Sosyal Fayda & 64.0 & 67.9 & 66.7 & 56.5 & 57.4 & 58.5 & 62.2 & 69.2 \\
\hline & Sosyal Fayda Kaybı & 36.0 & 32.1 & 33.3 & 43.5 & 42.6 & 41.5 & 37.8 & 30.8 \\
\hline & $\mathbf{N}$ & 61 & 61 & 61 & 61 & 61 & 61 & 61 & 61 \\
\hline \multirow{4}{*}{ 葋 } & Atkinson endeksi & 0.469 & 0.531 & 0.483 & 0.505 & 0.484 & 0.459 & 0.420 & 0.364 \\
\hline & Sosyal Fayda & 53.1 & 46.9 & 51.7 & 49.5 & 51.6 & 54.1 & 58.0 & 63.6 \\
\hline & Sosyal Fayda Kaybı & 46.9 & 53.1 & 48.3 & 50.5 & 48.4 & 45.9 & 42.0 & 36.4 \\
\hline & $\mathbf{N}$ & 77 & 77 & 77 & 77 & 77 & 77 & 77 & 77 \\
\hline \multirow{4}{*}{ 总 } & Atkinson endeksi & 0.757 & 0.738 & 0.744 & 0.803 & 0.788 & 0.767 & 0.735 & 0.692 \\
\hline & Sosyal Fayda & 24.3 & 26.2 & 25.6 & 19.7 & 21.2 & 23.3 & 26.5 & 30.8 \\
\hline & Sosyal Fayda Kaybı & 75.7 & 73.8 & 74.4 & 80.3 & 78.8 & 76.7 & 73.5 & 69.2 \\
\hline & $\mathbf{N}$ & 80 & 80 & 80 & 80 & 80 & 80 & 80 & 80 \\
\hline \multirow{4}{*}{ 离 葛 } & Atkinson endeksi & 0.401 & 0.443 & 0.396 & 0.468 & 0.434 & 0.400 & 0.350 & 0.285 \\
\hline & Sosyal Fayda & 59.9 & 55.7 & 60.4 & 53.2 & 56.6 & 60.0 & 65.0 & 71.5 \\
\hline & Sosyal Fayda Kaybı & 40.1 & 44.3 & 39.6 & 46.8 & 43.4 & 40.0 & 35.0 & 28.5 \\
\hline & $\mathbf{N}$ & 81 & 81 & 81 & 81 & 81 & 81 & 81 & 81 \\
\hline \multirow{4}{*}{ 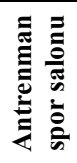 } & Atkinson endeksi & 0.849 & 0.826 & 0.836 & 0.886 & 0.874 & 0.857 & 0.830 & 0.794 \\
\hline & Sosyal Fayda & 15.1 & 17.4 & 16.4 & 11.4 & 12.6 & 14.3 & 17.0 & 20.6 \\
\hline & Sosyal Fayda Kaybı & 84.9 & 82.6 & 83.6 & 88.6 & 87.4 & 85.7 & 83.0 & 79.4 \\
\hline & $\mathbf{N}$ & 53 & 53 & 53 & 53 & 53 & 53 & 53 & 53 \\
\hline \multirow{4}{*}{ 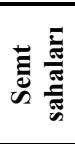 } & Atkinson endeksi & 0.930 & 0.922 & 0.925 & 0.945 & 0.940 & 0.932 & 0.920 & 0.905 \\
\hline & Sosyal Fayda & 7.0 & 7.8 & 7.5 & 5.5 & 6.0 & 6.8 & 8.0 & 9.5 \\
\hline & Sosyal Fayda Kaybı & 93.0 & 92.2 & 92.5 & 94.5 & 94.0 & 93.2 & 92.0 & 90.5 \\
\hline & $\mathbf{N}$ & 80 & 80 & 80 & 80 & 80 & 80 & 80 & 80 \\
\hline \multirow{4}{*}{ 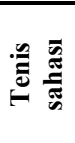 } & Atkinson endeksi & 0.776 & 0.738 & 0.755 & 0.831 & 0.813 & 0.789 & 0.750 & 0.695 \\
\hline & Sosyal Fayda & 22.4 & 26.2 & 24.5 & 16.9 & 18.7 & 21.1 & 25.0 & 30.5 \\
\hline & Sosyal Fayda Kaybı & 77.6 & 73.8 & 75.5 & 83.1 & 81.3 & 78.9 & 75.0 & 69.5 \\
\hline & $\mathbf{N}$ & 41 & 41 & 41 & 41 & 41 & 41 & 41 & 41 \\
\hline \multirow{4}{*}{ 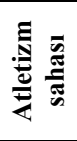 } & Atkinson endeksi & 0,456 & 0,462 & 0,438 & 0,531 & 0,504 & 0,466 & 0,417 & 0,359 \\
\hline & Sosyal Fayda & 54,4 & 53,8 & 56,2 & 46,9 & 49,6 & 53,4 & 58,3 & 64,1 \\
\hline & Sosyal Fayda Kaybı & 45.6 & 46.2 & 43.8 & 53.1 & 50.4 & 46.6 & 41.7 & 35.9 \\
\hline & $\mathbf{N}$ & 73 & 73 & 73 & 73 & 73 & 73 & 73 & 73 \\
\hline \multirow{4}{*}{ 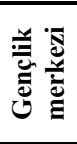 } & Atkinson endeksi & 0.623 & 0.611 & 0.607 & 0.682 & 0.663 & 0.637 & 0.597 & 0.541 \\
\hline & Sosyal Fayda & 37.7 & 38.9 & 39.3 & 31.8 & 33.7 & 36.3 & 40.3 & 45.9 \\
\hline & Sosyal Fayda Kaybı & 62.3 & 61.1 & 60.7 & 68.2 & 66.3 & 63.7 & 59.7 & 54.1 \\
\hline & $\mathbf{N}$ & 81 & 81 & 81 & 81 & 81 & 81 & 81 & 81 \\
\hline \multirow{4}{*}{ 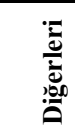 } & Atkinson endeksi & 0.612 & 0.673 & 0.619 & 0.655 & 0.620 & 0.583 & 0.545 & 0.506 \\
\hline & Sosyal Fayda & 38.8 & 32.7 & 38.1 & 34.5 & 38.0 & 41.7 & 45.5 & 49.4 \\
\hline & Sosyal Fayda Kaybı & 61.2 & 67.3 & 61.9 & 65.5 & 62.0 & 58.3 & 54.5 & 50.6 \\
\hline & $\mathbf{N}$ & 81 & 81 & 81 & 81 & 81 & 81 & 81 & 81 \\
\hline
\end{tabular}


Yaş dilimlerine göre vilayet nüfuslarının spor tesislerinden sağladıkları sosyal fayda kayıpları açısından konu irdelendiğinde de sosyal fayda kayıplarının daha çok 65 yaş üstü nüfus grup için düşük düzeyde kaldığı görülmektedir. Örneğin tüm spor tesislerinin vilayetlere göre dağılımlarındaki dengesizlikten kaynaklanan sosyal fayda kayıpları 65 yaş ve üstü yaş grubu için \%70,5'le sınırlıdır. 0-14 yaş grubu için \%76,8; $15-24$ yaş grubu için \%76,5; 25-34 yaş grubu için \%81,8; 35-44 yaş grubu için \%80,2; 45-54 yaş grubu için \%78; 55-64 yaş grubu için \%74,7; 65 yaş üstü nüfus için ise \%70,5 olarak gerçekleşmiştir.

Vilayet nüfus bütününe göre en yüksek sosyal faydanın sağlandığı spor tesisi türü olan stadyumlardan yaş dilimlerine göre nüfusun sosyal fayda kayıpları; 0-14 yaş grubu için \%32.1; 15-24 yaş grubu için \%32.3; 25-34 yaş grubu için \%43.5; 35-44 yaş grubu için \%42.6; 45-54 yaş grubu için \%41.5; 55-64 yaş grubu için \%37.8; 65 yaş üstü nüfus için ise \%30.8 olarak gerçekleşmiştir.

Vilayet nüfus bütününe göre ikinci en yüksek sosyal faydanın sağlandığ́ spor tesisi türü olan spor salonlarından yaş dilimlerine göre nüfusun sosyal fayda kayıpları; 0-14 yaş grubu için \%44.3; 15-24 yaş grubu için \%39.6; 25-34 yaş grubu için \%46.8; 35-44 yaş grubu için \%43.4; 45-54 yaş grubu için \%40; 55-64 yaş grubu için \%35; 65 yaş üstü nüfus için ise \%28.5 olarak gerçekleşmiştir.

Vilayet nüfus bütününe göre üçüncü en yüksek sosyal faydanın sağlandığı spor tesisi türü olan atletizm stadyumlarından yaş dilimlerine göre nüfusun sosyal fayda kayıpları; 0-14 yaş grubu için \%46.2; 15-24 yaş grubu için \%43.8; 25-34 yaş grubu için \%53.1; 35-44 yaş grubu için \%50.4; 45-54 yaş grubu için \%46.6; 55-64 yaş grubu için \%41.7; 65 yaş üstü nüfus için ise \%35.9 olarak gerçekleşmiştir.

Stadlardan yaş dilimlerine göre nüfusun sosyal fayda kayıpları; 0-14 yaş grubu için \%53.1; $15-24$ yaş grubu için \%48.3; 25-34 yaş grubu için \%50.5; 35-44 yaş grubu için \%48.4; 45-54 yaş grubu için \%45.9; 55-64 yaş grubu için \%42; 65 yaş üstü nüfus için ise \%36.4 olarak gerçekleşmiştir.

Diğer spor tesislerinden yaş dilimlerine göre nüfusun sosyal fayda kayıpları; 0-14 yaş grubu için \%67.3; $15-24$ yaş grubu için \%61.9; 25-34 yaş grubu için \%65.5; 35-44 yaş grubu için \%62; $45-54$ yaş grubu için \%58.3; 55-64 yaş grubu için \%54,5; 65 yaş üstü nüfus için ise \%50.6 olarak gerçekleşmiştir. 
Gençlik merkezlerinden yaş dilimlerine göre nüfusun sosyal fayda kayıpları; 0-14 yaş grubu için \%61.1; 15-24 yaş grubu için \%60.7; 25-34 yaş grubu için \%68.2; 35-44 yaş grubu için \%66.3; 45-54 yaş grubu için \%63.7; 55-64 yaş grubu için \%59.7; 65 yaş üstü nüfus için ise $\% 54.1$ olarak gerçekleşmiştir.

Futbol sahalarından yaş dilimlerine göre nüfusun sosyal fayda kayıpları; 0-14 yaş grubu için \%73.8; $15-24$ yaş grubu için \%74.4; 25-34 yaş grubu için \%80.3; 35-44 yaş grubu için \%66.3; 45-54 yaş grubu için \%63.7; 55-64 yaş grubu için \%59.7; 65 yaş üstü nüfus için ise $\% 54.1$ olarak gerçekleşmiştir.

Tenis sahalarından yaş dilimlerine göre nüfusun sosyal fayda kayıpları; 0-14 yaş grubu için \%73.8; 15-24 yaş grubu için \%75,5; 25-34 yaş grubu için \%83.1; 35-44 yaş grubu için \%81.3; $45-54$ yaş grubu için \%78.9; 55-64 yaş grubu için \%75; 65 yaş üstü nüfus için ise \%69.5 olarak gerçekleşmiştir.

Antrenman spor sahalarından yaş dilimlerine göre nüfusun sosyal fayda kayıpları; 014 yaş grubu için \%82.6; 15-24 yaş grubu için \%83.6; 25-34 yaş grubu için \% $\%$ 78.6; 35-44 yaş grubu için \%77.4; 45-54 yaş grubu için \%75.7; 55-64 yaş grubu için \%83; 65 yaş üstü nüfus için ise \%79.4 olarak gerçekleşmiştir.

Semt sahalarından yaş dilimlerine göre nüfusun sosyal fayda kayıpları; 0-14 yaş grubu için \%92.2; 15-24 yaş grubu için \%92,5; 25-34 yaş grubu için \%94,5; 35-44 yaş grubu için \%94; 45-54 yaş grubu için \%93.2; 55-64 yaş grubu için \%92; 65 yaş üstü nüfus için ise \%90,5 olarak gerçekleşmiştir.

Sosyal fayda kayıpları, hissedilemeyen diğer bir deyişle yok olarak hissedilen kısmın yüzdesini tanımladığından, bir sonraki aşama olarak spor tesislerinin genel nüfus ve yaş gruplarına göre nüfuslar tarafindan hangi miktarda hissedildiği ile hissedilemeyen yani yok olarak hissedilenlerinin miktarları hesaplanmıştır. Buna göre elde edilen bulgular tablo 3' te özetlenmiştir.

Tüm spor tesisleri dikkate alınarak yapılan analizde, ülkemizdeki spor tesislerinin il nüfuslarına göre dengeli dağıtılamamasından dolayı nüfusun 9284 adet olan toplam spor tesisi yekununu 2091 adetmiş gibi hissetmekte olup, 7193 spor tesisi yokmuş gibi hissedilmektedir. Semt sahalarında ise \%7'yle sınırlı kalan sosyal fayda düzeyi neticesinde 6082 semt sahasının sadece 428 adetmiş gibi hissedilebildiği, 5654 adetinse yokmuş gibi hissedildiği görülmektedir. Vilayetlerdeki genel nüfusa göre en yüksek sosyal faydanın sağlandığı spor tesisi türünü oluşturan stadyumlarda ise mevcut 74 stadyumun 47 stadyum gibi hissedilebilmekte olup, 27 stadyumun ise yokmuş gibi hissedilmektedir. 
Tablo 3. Atkinson Endeksleri, Sosyal Fayda Oranları, Sosyal Fayda Kayıp Oranları

\begin{tabular}{|c|c|c|c|c|c|c|c|c|c|}
\hline & & Genel nüfus & $0-14$ & $15-24$ & $25-34$ & $35-44$ & $45-54$ & 55-64 & $65+$ \\
\hline \multirow{4}{*}{ 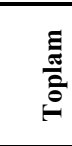 } & Atkinson katsayısı & 0,775 & 0,768 & 0,765 & 0,818 & 0,802 & 0,780 & 0,747 & 0,705 \\
\hline & Mevcut tesis sayısı & 9284 & 9284 & 9284 & 9284 & 9284 & 9284 & 9284 & 9284 \\
\hline & Mevcudiyeti hissedilen tesis sayısı & 2091 & 2152 & 2184 & 1686 & 1839 & 2046 & 2353 & 2740 \\
\hline & Mevcudiyeti hissedilmeyen tesis sayısı & 7193 & 7132 & 7100 & 7598 & 7445 & 7238 & 6931 & 6544 \\
\hline \multirow{4}{*}{ 莡 } & Atkinson katsayısı & 0,360 & 0,321 & 0,333 & 0,435 & 0,426 & 0,415 & 0,378 & 0,308 \\
\hline & Mevcut tesis sayısı & 74 & 74 & 74 & 74 & 74 & 74 & 74 & 74 \\
\hline & Mevcudiyeti hissedilen tesis sayısı & 47 & 50 & 49 & 42 & 42 & 43 & 46 & 51 \\
\hline & Mevcudiyeti hissedilmeyen tesis sayısI & 27 & 24 & 25 & 32 & 32 & 31 & 28 & 23 \\
\hline \multirow{4}{*}{ 吾 } & Atkinson katsayısı & 0,469 & 0,531 & 0,483 & 0,505 & 0,484 & 0,459 & 0,420 & 0,364 \\
\hline & Mevcut tesis sayısı & 282 & 282 & 282 & 282 & 282 & 282 & 282 & 282 \\
\hline & Mevcudiyeti hissedilen tesis sayısı & 150 & 132 & 146 & 140 & 145 & 153 & 164 & 179 \\
\hline & Mevcudiyeti hissedilmeyen tesis sayısI & 132 & 150 & 136 & 142 & 137 & 129 & 118 & 103 \\
\hline \multirow{4}{*}{ 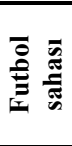 } & Atkinson katsayısı & 0,757 & 0,738 & 0,744 & 0,803 & 0,788 & 0,767 & 0,735 & 0,692 \\
\hline & Mevcut tesis sayısı & 1352 & 1352 & 1352 & 1352 & 1352 & 1352 & 1352 & 1352 \\
\hline & Mevcudiyeti hissedilen tesis sayısı & 329 & 354 & 346 & 266 & 287 & 314 & 358 & 417 \\
\hline & Mevcudiyeti hissedilmeyen tesis sayısı & 1023 & 998 & 1006 & 1086 & 1065 & 1038 & 994 & 935 \\
\hline \multirow{4}{*}{ 玄 } & Atkinson katsayısı & 0,401 & 0,443 & 0,396 & 0,468 & 0,434 & 0,400 & 0,350 & 0,285 \\
\hline & Mevcut tesis sayısı & 423 & 423 & 423 & 423 & 423 & 423 & 423 & 423 \\
\hline & Mevcudiyeti hissedilen tesis sayısı & 253 & 236 & 256 & 225 & 239 & 254 & 275 & 303 \\
\hline & Mevcudiyeti hissedilmeyen tesis sayısI & 170 & 187 & 167 & 198 & 184 & 169 & 148 & 120 \\
\hline \multirow{4}{*}{ 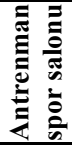 } & Atkinson katsayısı & 0,849 & 0,826 & 0,836 & 0,886 & 0,874 & 0,857 & 0,830 & 0,794 \\
\hline & Mevcut tesis sayısı & 180 & 180 & 180 & 180 & 180 & 180 & 180 & 180 \\
\hline & Mevcudiyeti hissedilen tesis sayısı & 27 & 31 & 30 & 20 & 23 & 26 & 31 & 37 \\
\hline & Mevcudiyeti hissedilmeyen tesis sayısI & 153 & 149 & 150 & 160 & 157 & 154 & 149 & 143 \\
\hline \multirow{4}{*}{ 莺 } & Atkinson katsayısı & 0,930 & 0,922 & 0,925 & 0,945 & 0,940 & 0,932 & 0,920 & 0,905 \\
\hline & Mevcut tesis sayısı & 6082 & 6082 & 6082 & 6082 & 6082 & 6082 & 6082 & 6082 \\
\hline & Mevcudiyeti hissedilen tesis sayısı & 428 & 473 & 457 & 335 & 367 & 414 & 486 & 576 \\
\hline & Mevcudiyeti hissedilmeyen tesis sayısI & 5654 & 5609 & 5625 & 5747 & 5715 & 5668 & 5596 & 5506 \\
\hline \multirow{4}{*}{ 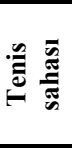 } & Atkinson katsayısı & 0,776 & 0,738 & 0,755 & 0,831 & 0,813 & 0,789 & 0,750 & 0,695 \\
\hline & Mevcut tesis sayısı & 119 & 119 & 119 & 119 & 119 & 119 & 119 & 119 \\
\hline & Mevcudiyeti hissedilen tesis sayısı & 27 & 31 & 29 & 20 & 22 & 25 & 30 & 36 \\
\hline & Mevcudiyeti hissedilmeyen tesis sayısI & 92 & 88 & 90 & 99 & 97 & 94 & 89 & 83 \\
\hline \multirow{4}{*}{ 䨔 } & Atkinson katsayısı & 0,849 & 0,826 & 0,836 & 0,886 & 0,874 & 0,857 & 0,830 & 0,794 \\
\hline & Mevcut tesis sayısı & 156 & 156 & 156 & 156 & 156 & 156 & 156 & 156 \\
\hline & Mevcudiyeti hissedilen tesis sayısı & 24 & 27 & 26 & 18 & 20 & 22 & 26 & 32 \\
\hline & Mevcudiyeti hissedilmeyen tesis sayısI & 132 & 129 & 130 & 138 & 136 & 134 & 130 & 124 \\
\hline \multirow{4}{*}{ 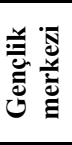 } & Atkinson katsayısı & 0,623 & 0,611 & 0,607 & 0,682 & 0,663 & 0,637 & 0,597 & 0,541 \\
\hline & Mevcut tesis sayısı & 132 & 132 & 132 & 132 & 132 & 132 & 132 & 132 \\
\hline & Mevcudiyeti hissedilen tesis sayısı & 50 & 51 & 52 & 42 & 44 & 48 & 53 & 61 \\
\hline & Mevcudiyeti hissedilmeyen tesis sayısI & 82 & 81 & 80 & 90 & 88 & 84 & 79 & 71 \\
\hline \multirow{4}{*}{ 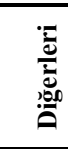 } & Atkinson katsayısı & 0,612 & 0,673 & 0,619 & 0,655 & 0,620 & 0,583 & 0,545 & 0,506 \\
\hline & Mevcut tesis sayısı & 484 & 484 & 484 & 484 & 484 & 484 & 484 & 484 \\
\hline & Mevcudiyeti hissedilen tesis sayısı & 188 & 158 & 184 & 167 & 184 & 202 & 220 & 239 \\
\hline & Mevcudiyeti hissedilmeyen tesis sayısI & 296 & 326 & 300 & 317 & 300 & 282 & 264 & 245 \\
\hline
\end{tabular}

Vilayet genel nüfuslarına göre dağılım dengesizliği sebebiyle en yüksek sosyal faydanın sağlandığı spor tesislerinden en düşük sosyal faydanın sağlandığı spor tesislerine doğru mevcut - hissedilen - hissedilemeyen (yokmuş gibi hissedilen spor tesis miktarları ise şu şekilde gerçekleşmiştir: Stadlarda 282 mevcut stad 150’ymiş gibi hissedilirken hissedilmeyen 132 tesisdir; spor salonlarında 423 mevcut 253'müş gibi hissedilirken hissedilemeyen 170 tesistir; atletizm stadyumlarında 156 mevcut 24'müş gibi hissedilirken hissedilemeyen 132 tesistir; diğer spor tesislerinde 484 mevcut 188'miş gibi hissedilirken hissedilemeyen 296 tesistir; gençlik merkezlerinde 132 mevcut 50'ymiş gibi hissedilirken 
hissedilemeyen 82 tesistir; futbol sahalarında 1352 mevcut 329'muş gibi hissedilirken hissedilemeyen 1023 tesistir; tenis sahalarında 119 mevcut 27’ymiş gibi hissedilirken hissedilemeyen 92 tesistir; antrenman spor salonlarında 180 mevcut 27'ymiş gibi hissedilirken hissedilemeyen 153 tesistir. Yaş dilimlerine göre vilayet nüfuslarının hissedip hissedemediği spor tesis sayıları da ayrıca tabloda yer almaktadır (Bkz. Tablo 3).

\section{TARTIŞMA VE SONUÇ}

Günümüzde sportif faaliyetler, hem mesleki amaçlı hem de rekreatif amaçlı olarak yoğun şekilde tercih edilen ve talep gören faaliyet alanlarından birisini oluşturmaktadır. Bu kapsamda da kamunun yoksunluğu giderici politikalarına doğru genişleyen faaliyet tanımı kapsamında sosyal politika konusunda önemli bir yer işgal ettiğinin savunulması mümkündür. Dolayısıyla da gerek mesleki gerekse de rekreatif amaçlı olarak takip edilen sportif faaliyetlerin gerçekleştirileceği alanların kamu eliyle veya desteğiyle tesisi ihtiyacıyla karşılaşılmaktadır. Mevcut spor tesislerinin ülke genel nüfusu ve yaş dilimlerine göre nüfusunun ihtiyaçlarını karşılayıp-karşılayamadığı ya da hangi spor tesis türlerinde öncelikli ihtiyacın bulunduğunun tespiti ise uluslararası mukayeselerle ya da talepleri ortaya koyacak ve bu doğrultuda arzın talebi karşılayıp - karşılayamadığını sorgulayacak alan çalışmalarıyla tespit edilebilir. Bu çalışmada odaklanılan temel sorun ise, mevcut donatının ihtiyaca cevap verip verememe yeterliliğinin tespiti olmayıp, mevcut tesis yekununun ne ölçüde vilayetler arasında vilayet genel ve yaş dilimlerine göre nüfuslarıyla dengeli dağıtılabildiğine yanıt aranmasidir.

Çalışma kapsamında gerçekleştirilen analizler neticesinde genel olarak spor tesislerinin vilayet genel ve yaş dilimlerine göre nüfuslarıyla ciddi ölçüde örtüşmeyecek şekilde dengesiz dağıtıldığını göstermektedir. Mesleki anlamda faaliyet sahası olarak sportif faaliyetleri seçenler açısından özellikle 0-14 yaş grubu ve 15-24 yaş grubundaki vilayet nüfusları ön plana çıkmaktadır. Bu kapsamda bakıldığında da diğer yaş dilimlerinde olduğu gibi tüm spor tesis türlerinden sağlanan sosyal fayda kayıplarının oldukça yüksek olduğu tespit edilmiş olup, bu sebeple de Atkinson yaklaşımındaki tanım gereği mevcut tesislerin önemli bölümünün ilgili yaş dilimindekilerce varlığı hissedilememektedir. Ancak yaş dilimleri arasında mukayese yapıldığında, 0-14 ile 15-24 yaş grubundaki nüfusun genel olarak 25-34; 35-44 ve 45-54 yaş grubundakilere göre mevcut spor tesislerini daha yüksek oranda hissedebildikleri sonucuyla da karşılaşılmaktadır. 
Genel olarak 15-24 yaş grubu ile 55-64 yaş grubundakiler açısından birbirine yakın hissetme oranlarına ulaşıldığı, 0-14 ile 65 yaş ve üzerindekiler arasında da benzer 15-24 ile 55-64 yaş grubundakiler arasındakine benzeyen bir benzeşimin mevcut olduğu dikkat çekmektedir. 0-14 ile 15-24 yaş grubundakilerin ve özellikle de 0-14 yaş gurubundakilerin mesleki potansiyel olarak önem taşımalarına karşılık 55-64 ve özellikle de 65 yaş ve üzerindekiler açısından böyle bir potansiyelin çok da mümkün olmadığı açıktır. Kaldıki rekreatif amaçlı faaliyet olarak sportif faaliyetlerin tercihinin, 55-64 ve 65 yaş ve üstü açısından öneminin de 25-34; 35-44; 45-54 yaş gruplarına göre daha düşük düzeyde olacağ1 bir realitedir. Neticede ülkemizde çalışma hayatı açısından konu ele alındığında, 55 yaş ve üzerindekiler içerisinde aktif çalışanların sınırlılığı, boş zamana duyulan ihtiyacı da azaltacak ölçülerdedir. Neticede fiziksel güç açısından da 55 yaş ve üstündekilerin rekreatif faaliyet olarak sportif faaliyetleri tercih etmeleri, 25-54 yaş arasındakilere göre düşük olacaktır. Dolayısıyla 55 yaş ve üstündekilerin vilayet nüfus miktarlarıyla daha dengeli bir dağılımın mevcut olmasını, ne mesleki ne de rekreatif amaçlı faaliyetleri desteklemeye bağlantılandırma imkânı bulunmaktadır.

Tesislerin doğrudan kamu eliyle kurulması veya kamunun desteğiyle kurdurulması kapsamında mesleki amaçlı faaliyet dışında rekreatif amaçlı faaliyet özelliğinde kabul edilip edilmediğini ise 25-54 yaş dilimi açısından yorumlama imkânı mevcuttur. Şayet Rekreatif amaç ön plana çıkartılmış olsaydı, bu yaş aralığındaki üç yaş dilimi açısından daha dengeli dağılımın sağlanması gerekirdi. Ancak elde edilen bulgular, mevcut dengesiz dağılımın yanı sıra yaş dilimleri arasındaki farklılaşmadan hareketle rekreatif amaçlı faaliyet kapsamında değerlendirilmediğini desteklemektedir.

Kamunun mesleki faaliyet-rekreatif faaliyet algılaması ikilemindeki duruşunu özetlersek, ilk bakışta mesleki faaliyet olarak algının ön plana çıktığı savunulabilecektir. Ancak TUIK verilerine göre ülkemizde sadece futbol branşında amatör futbolcu sayısının yarım milyonu aştığı bir ülkede 1352 futbol sahasının ve 6082 semt sahasının bulunması oldukça yetersizdir. Kaldıki 1352 futbol sahasının 0-14 yaş dilimindekilerce 998'inin hissedilemediği ve sadece 354 futbol sahası varmış gibi hissedildiği bir ortamda, sürekli idmanın gerektiği düşünüldüğünde böyle bir bakışın da rasyonel şekilde mevcut olduğunu savunmak güçleşmektedir. Keza 6082 semt sahasının yine 0-14 yaş dilimince 5609'inin hissedilemeyip 473 semt sahası varmış gibi hissedilmesi de bu durumu destekleyen bir diğer göstergeyi oluşturmaktadır. İlk yetişme dönemi ertesinde aktif sporculuk açısından önemli bir 
yaş dilimi özelliğini taşıyan 15-24 yaş dilimi açısından bulguların benzer olması da bir diğer destekleyici bulguyu oluşturmaktadır.

Sayısal olarak spor tesislerinin ihtiyacı karşılamada yetersiz olduğu savunulabilir. Ancak daha kritik olan nokta, tesis türlerinin içerisinde \%93'e ulaşan fayda kaybının yaşanmasına sebep olacak düzeyde dengesizliğin oluşu çok daha önemlidir. Mevcut spor tesislerinin yerlerini dengeli dağılım sağlanacak şekilde yer değiştirme imkanı fiziken mümkün olmadığına göre, yeni tesis inşalarının tam denge durumuna yaklaştıracak ölçüde dağıtımının yapılarak yoksunluğun en yoğun yaşandığı vilayetlere odaklanılması ihtiyacı ile karşılaşılmaktadır.

\section{REFERENCES}

- Ardahan F, Yerlisu Lapa T. (2010). Açıkalan rekreasyonu: bisiklet kullanıcıları ve yürüyüşçülerin doğa sporu yapma nedenleri ve elde ettikleri faydalar. Uluslararas1 İnsan Bilimleri Dergisi, 8(1): 1327-1341.

- Atasoy B, Öztürk Kuter F. (2005). Küreselleşme ve spor. Eğitim Fakültesi Dergisi, 18(1), 2005, 11-22

- Bleys B. (2013). The regional index of sustainable economic welfare for Flanders, Belgium. Sustainability, 5(2): 496-523.

- Çiftçi M. (2009). Servetin bölgesel dağılımı perspektifiyle türkiye' nin ab' ye uyum sorunu. İstanbul: İstanbul Üniversitesi İktisat Fakültesi Ekonometri Bölümü Yayını.

- Filiz K. (2002). Sporun tanımlanması ve kapsamının belirlenmesi üzerine bir çalışma. Gazi Üniversitesi Gazi Eğitim Fakültesi Dergisi, 22(2): 203-211.

- Sunay H, Saracaloğlu AS. (2003). Türk sporcusunun spordan beklentileri ile spora yönelten unsurlar. SPORMETRE Beden Eğitimi ve Spor Bilimleri Dergisi, 1(1): 4348.

- Şahan H. (2008). Üniversite öğrencilerinin sosyalleşme sürecinde spor aktivitelerinin rolü. Karamanoğlu Mehmet Bey Üniversitesi İİBF Dergisi, 10 (15): 206-278.

- Tanyeri Y. (2003). Sanat ve spor. Journal of Fine Arts, 4: 147-151.

- Tel M, Köksalan B. (2008). Öğretim üyelerinin spor etkinliklerinin sosyolojik olarak incelenmesi (Doğu Anadolu örneği). Frrat Üniversitesi Sosyal Bilimler Dergisi, 18(1): $261-278$.

- Villaverde J, Maza A. (2012). Chinese per Capita income distribution, 1992-2007: A regional perspective. Asian Economic Journal, 26(4): 313-331.

- Zelyurt MK. (2013). Türk modernleşmesinde spor: Tanzimat' tan erken cumhuriyete. Turkish Studies, 8(12): 1461-1478.

- Zengin E, Öztaş C. (2008). Yerel yönetimler ve spor. İktisat Fakültesi Sosyal Siyaset Konferanslar1, 55: 49-78.

- Wan, G, Lu M, Chen Z. (2007). Globalization and regional income inequality: empirical evidence from within China. Review of Income and Wealth, 53(1): 35-59. 
- Dayığlu M, Başlevent C. (2006). Imputed rents and regional income inequality in Turkey: a subgroup decomposition of the Atkinson index. Regional Studies, 40(8): 889-905.

- Castro JV. (2003). Regional convergence, polarisation and mobility in the European Union, 1980-1996. Journal of European Integration, 25(1): 73-86.

- Chen J, Fleisher, BM. (1996). Regional income inequality and economic growth in China. Journal of comparative economics, 22(2): 141-164.

- Islam I, Khan, H. (1986). Spatial patterns of inequality and poverty in Indonesia. Bulletin of Indonesian Economic Studies, 22(2): 80-102.

- Mizak D, Stair A, Rossi, A. (2005). Assessing alternative competitive balance measures for sports leagues: a theoretical examination of standard deviations, Gini coefficients, the index of dissimilarity. Economics Bulletin, 12(5): 1-11.

- Mizak D, Neral J, Stair A. (2007). The adjusted churn: an index of competitive balance for sports leagues based on changes in team standings over time. Economics Bulletin, 26(3): 1-7.

- Wiseman, F, Chatterjee S. (2003). Team payroll and team performance in major league baseball: 1985-2002. Economics Bulletin, 1(2): 1-10.

- Owen PD, King N. (2015). Competitive balance measures in sports leagues: The effects of variation in season length. Economic Inquiry, 53(1): 731-744.

- Owen PD. (2010). Limitations of the relative standard deviation of win percentages for measuring competitive balance in sports leagues. Economics Letters, 109(1): 3841.

- Annala, CN, Winfree J. (2011). Salary distribution and team performance in Major League Baseball. Sport Management Review, 14(2)): 167-175.

- Çiftçi M. (2010). Türkiye'de 60 yaş ve üstü nüfusun sağlık hizmetlerinin bölgesel dağılımından sağladıkları sosyal fayda düzeyleri. Turkish Journal of Geriatrics, 13(4): 252-260.

- Çiftçi M, Seymen, R. (2012). Türkiye'de hanedanlıktan cumhuriyete ortaokul öğrencilerinin öğretmenlerden sağladıkları sosyal fayda düzeylerinin Atkinson bölgesel eşitsizlik endeksi yaklaşımıyla ölçümü (1897 ve 1997). Uluslar arası İnsan Bilimleri Dergisi, 9 (2): 815-830.

- Çiftçi M. (2011). Türkiye'de iç göçte sosyal ağ kullanımı üzerindeki etkenler. Sosyo Ekonomi Dergisi, 7(15): 105-124.

- Çiftçi M, Seymen, R. (2011). Türkiye'de 1995'ten 2004'e kamusal sağlık hizmetlerinde bölgelerarası uyumlaşma süreci. Uluslar arası İnsan Bilimleri Dergisi, 8(2): 1073-1089.

- TUİK (Türkiye İstatistik Kurumu). (2008). Spor istatistikleri, 2007. Ankara: TUİK yayınları.

- Harvey J. (2005). A note on the 'natural rate of subjective inequality'hypothesis and the approximate relationship between the Gini coefficient and the Atkinson index. Journal of Public Economics, 89: 1021-1025.

- García I, Molina JA. (2001). The effects of region on the welfare and monetary income of Spanish families. Urban Studies, 38 (13): 2415-2424.

- Salas R. (1997). "Welfare-consistent inequality indices in changing populations: The marginal population replication axiom A note. Journal of Public Economics, 67: 145150.

- Pedersen AW. (2004). Measurement Inequality as Relative Deprivation: A Sociological Approach to Inequality. Acta Sociologica, 47: 31-49. 
- Atkinson AB. (1970). On the measurement of inequality. Journal of Economic Theory, 2: 244-263.

- Öztürk L. (2005). Bölgelerarası gelir eşitsizliği: istatistikî bölge birimleri sınıflandırması'na (İBBS) göre eşitsizlik indeksleri ile bir analiz, 1965-2001. Akdeniz İ.İ.B.F. Dergisi, 10: 95-110.

- Spatz J. (2006). Poverty and inequality in the era of structural reforms: The case of Bolivia. Springer Verlag, Berlin.

- Regidor E, Calle ME, Navarro P, Dominguez V. (2003). Trends in the association between average income, poverty and income inequality and life expectancy in Spain. Social Science \& Medicine, 56: 961-971. 